\title{
RUSSIAN NOMINAL FLEXION
}

\author{
F. H. H. KORTLANDT
}

\section{INTRODUCTION}

In this article I intend to give a description of the flexion of the Russian nominal system in terms of morphonemes. The description is based chiefly on Zaliznjak 1967. Following Russian usage I include morphonemes in \langle\rangle .

A purely functional approach to the phonemic level of language leads inevitably to the assumption of archiphonemes. ${ }^{1}$ On the morphonemic level, however, the use of archiphonemes is cumbersome and can be avoided by the introduction of morphonemes. These units stand for phonemes or sequences of phonemes that pattern like single phonemes (e.g., affricates and diphthongs in various languages) and for archiphonemes that alternate with the corresponding phonemes. If the morphonemic interpretation of an archiphoneme is impossible due to the absence of relevant alternation with a "full" phoneme, and considerations of simplicity or pattern congruity do not yield a decisive criterion, the phonetic facts can be taken into account in order to reach a unique solution, e.g., корова /karóva/〈karóva〉 'cow'. Since the number of units operative at the morphonemic level should be kept to a minimum, no "hyperphonemes" are assumed." Thus, the automatic alternation between phonemes and archiphonemes within a morpheme is satisfactorily described by the correspondence rules between the phonemic and the morphonemic level of the language.

\section{RUSSIAN MORPHONEMES}

2.1. Vowels: $\langle\mathrm{i}\rangle,\langle\mathrm{y}\rangle,\langle\mathrm{e}\rangle,\langle\varepsilon\rangle,\langle\mathrm{a}\rangle,\langle\mathrm{o}\rangle,\langle\mathrm{u}\rangle,\langle\varnothing\rangle$. $\langle\mathrm{i}, \mathrm{y}\rangle=|\mathrm{i} / \sim| \mathrm{i} / \sim \mid \mathrm{I} /$.

1 Cf. Kortlandt, 1972a:131 ff.

2 Cf. Panov, 1967:235 ff. 


$$
\begin{aligned}
& \langle\mathrm{e}, \varepsilon\rangle=|\mathrm{e} / \sim| \mathrm{l}|\sim| \mathrm{I} / . \\
& \langle\mathrm{a}\rangle=|\mathrm{a} / \sim| \mathrm{a} / \sim \mid \mathrm{I} / . \\
& \langle\mathrm{o}\rangle=|\mathrm{o} / \sim| \mathrm{a} / \sim / \mathrm{I} / . \\
& \langle\mathrm{u}\rangle=\mid \mathrm{u} / \sim / \mathrm{U} / .
\end{aligned}
$$

1. The positions in which the various phonemes and archiphonemes occur are described in Kortlandt 1973a:74f.

2. The morphonemes $\langle i\rangle$ and $\langle e\rangle$ palatalize a preceding hard consonant if it has a soft counterpart. Examples: белить $\langle$ bel-i-it $\mathbf{t}\rangle$, белеть $\langle$ bel-é-t $\rangle$.

3. The morphoneme $\langle\varnothing\rangle$ is phonemically either zero or an infixed $\langle e\rangle$ or $\langle 0\rangle$. I am unable to give a simple rule for the choice between the zero and the nonzero variant. ${ }^{3}$ The nonzero variant is infixed before the consonant preceding the $\langle\varnothing\rangle$. The infix is $\langle\mathrm{e}\rangle$ before $\langle\mathrm{c}\rangle,\langle\mathrm{c}\rangle$ and soft sonorants $(\langle\dot{\mathrm{m}}\rangle,\langle\dot{\mathrm{n}}\rangle,\langle\mathrm{l}\rangle,\langle\dot{\mathrm{r}}\rangle,\langle\mathrm{j}\rangle)$ unless it is preceded by a velar consonant, and $\langle\mathrm{o}\rangle$ elsewhere. Examples: $\langle\mathrm{e}\rangle$ in день, отец, волчец, заяц, жечь, восемь, ремень, воробей, лисий, третий, овец, деревень, капель, статей, копий, каменья $\langle$ kamn- $\dot{\varnothing} \mathrm{j}-\mathrm{a}\rangle$, чей $\langle\check{c}-\varnothing \mathrm{j}-\dot{\varnothing}\rangle,\langle\mathrm{o}\rangle$ in лёд, ложь, зол, огонь, уголь, угорь, песок, тонок, должен, овёс, ломоть, любовь, кухонь, сказок, каём, сестёр, серёг, уголья $\langle$ úgl-Øj-a $\rangle$, донья $\langle$ dn-Ǿj-a $\rangle$, сотый $\langle$ st- $\dot{\varnothing}-y j\rangle$. Exceptions: $\langle\mathrm{e}\rangle$ in

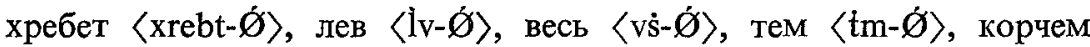

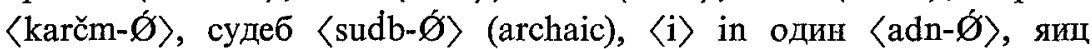

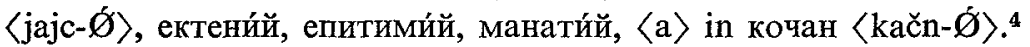

4. Morphonemic stress is present in monosyllabic as well as in polysyllabic word forms. ${ }^{5}$ When $\langle\emptyset\rangle$ is phonemically zero, the accent shifts to the preceding vowel.

5. If the ending is stressed, the stress is on the first syllable of the ending unless indicated otherwise.

\subsection{Consonants.}

2.2.1. Hard consonants.

$$
\begin{aligned}
& \text { Labials: }\langle\mathrm{p}\rangle,\langle\mathrm{b}\rangle,\langle\mathrm{f}\rangle,\langle\mathrm{v}\rangle,\langle\mathrm{m}\rangle . \\
& \langle\mathrm{p}\rangle=|\mathrm{p} / \sim| \mathrm{p} / \sim|\mathrm{P}| \sim \mid \mathrm{P} /, \text { etc. } \\
& \text { Dentals: }\langle\mathrm{t}\rangle,\langle\mathrm{d}\rangle,\langle\mathrm{c}\rangle,\langle\mathrm{s}\rangle,\langle\mathrm{z}\rangle,\langle\mathrm{n}\rangle,\langle\mathrm{l}\rangle,\langle\mathrm{r}\rangle . \\
& \langle\mathrm{s}\rangle=|\mathrm{s} / \sim| \mathrm{s} / \sim|\mathrm{S} / \sim| \mathrm{S} / \sim \mid \Sigma /, \text { etc. }
\end{aligned}
$$

3 Cf. Gr 1970:479ff.; Zaliznjak, 1967:268ff.

4 The new Academic Grammar gives (incorrectly) the form хребёт instead of хребе́т (Gr 1970:481) and does not mention the form яи́ц. Incidentally, the word form весь (not * ${ }_{\mathrm{B}} \mathrm{ë}$ ) is not covered by Zaliznjak's system of rules (1967:259 ff.).

5 Cf. Kortlandt, 1972b:57. Phonemic stress is neutralized in monosyllabic words. 
$\langle\mathrm{c}\rangle=|\underline{\mathrm{T}} \mathrm{s} / \sim| \underline{\mathrm{T}} \mathrm{s} / \ldots$

Palatals: $\langle\breve{\mathrm{s}}\rangle,\langle\breve{z}\rangle$.

Velars: $\langle\mathrm{k}\rangle,\langle\mathrm{g}\rangle,\langle\mathrm{x}\rangle$.

2.2.2. Soft consonants.

Labials: $\langle\dot{\mathrm{p}}\rangle,\langle\dot{\mathrm{b}}\rangle,\langle\dot{\mathrm{f}}\rangle,\langle\dot{\mathrm{v}}\rangle,\langle\dot{\mathrm{m}}\rangle$.

Dentals: $\langle\dot{\mathrm{t}}\rangle,\langle\dot{\mathrm{d}}\rangle,\langle\dot{\mathrm{s}}\rangle,\langle\dot{\mathrm{z}}\rangle,\langle\dot{\mathrm{n}}\rangle,\langle\mathrm{l}\rangle,\langle\dot{\mathrm{r}}\rangle$.

Palatals: $\langle\check{\mathrm{c}}\rangle,\langle\mathrm{j}\rangle$.

Velars: $\langle\mathrm{k}\rangle,\langle\dot{\mathrm{g}}\rangle,\langle\dot{\mathrm{x}}\rangle$.

1. The positions in which the various phonemes and archiphonemes occur are described in Kortlandt 1973a:77ff.

2. Intervocalic $\langle j\rangle$ is phonemically zero if it is preceded or followed by $/ \mathrm{i} /, \mid \mathrm{l} /, / \mathrm{I} /$. Word-initial $\langle\mathrm{j}\rangle$ is phonemically zero if it is followed by $/ \mathrm{i} /$.

3. Velar consonants are soft before suffix-initial $\langle y\rangle$, e.g., руки́ $\langle$ ruk-ý $\rangle$, ру́ки $\langle\text { rúk-y }\rangle^{6}$

\section{NOUN CATEGORIES}

3.1. There are six CASES: nominative ' $N$ ', accusative ' $A$ ', genitive ' $G$ ', locative ' $L$ ', dative ' $D$ ', instrumental ' $I$ '. Some nouns have a second genitive 'G2', a third genitive 'G3', or a second locative 'L2'.'

3.2. There are two NUMBers: singular 'sg' and plural 'pl'.

3.3. There are three concord classes, traditionally called "GENDERS": masculine ' $\underline{m}$ ', feminine ' $\underline{\text { ', }}$, and neuter ' $\underline{n}$ '. In the plural there is no gender distinction except in the words два, две 'two' and оба, обе 'both'.

3.4. There are five FLEXION CLASSES: the first '(1)', second '(2)', and third '(3)' declension of traditional grammar, ${ }^{8}$ the adjectival flexion '(4)', and the class of uninflected nouns '(5)'. Uninflected nouns have no case endings. There are no $\underline{f}(1)$ and no n $(2)$ nouns. There is one m (3) noun: путь 'way'. In the plural there is no distinction between the flexion classes (1), (2), (3). Proper names and place-names ending in the stem formatives $\langle o v\rangle,\langle$ in $\rangle$ belong to class (1) or (4) in the singular and to class (4) in the plural.

- This rule is lacking for the Gsg of words belonging to the second flexion class in Gr 1970:386, where it is formulated for the $\mathrm{Npl}$ only.

7 Since $\mathrm{G} 2=\mathrm{D}$ for all nouns which have a $\mathrm{G} 2$ different from $\mathrm{G}$, it would seem more appropriate to regard $G 2$ as a special syntactic use of $D$ rather than as a separate case form. This does not hold for the count form G3, which is a morphologically as well as syntactically distinct class.

8 Cf. Durovič, 1964; Isačenko, 1968; Shapiro, 1969; Stankiewicz, 1968. 
3.5. There are two major and four minor ACCENT CLASSES: the class of nouns with fixed stress ' $I$ ', the class of nouns with fixed sg stress and fixed $\mathrm{pl}$ stress but opposition between sg and $\mathrm{pl}$ stress ' $\mathrm{II}$ ', the classes of nouns with fixed sg stress and mobile pl stress 'Ia' 'IIa', and the classes of nouns with mobile sg stress ' $\mathrm{Ib}$ ' 'IIb'.

\section{CASE ENDINGS}

\subsection{Singular.}

$\mathrm{N}(1) \underline{\mathrm{m}}\langle\varnothing\rangle, \underline{\mathrm{n}}\langle\mathrm{o}\rangle,(2)\langle\mathrm{a}\rangle,(3)\langle\varnothing\rangle$, (4) $\underline{\mathrm{m}}\langle\mathrm{oj}\rangle,\langle\mathrm{yj}\rangle, \underline{\mathrm{n}}\langle\mathrm{ojo}\rangle$, $\underline{\mathrm{f}}\langle\mathrm{aja}\rangle$.

A (1) $\underline{\underline{m}}\left\langle^{*}\right\rangle, \underline{\underline{n}}\langle\mathbf{o}\rangle,(2)\langle u\rangle,(3)\langle\varnothing\rangle$, (4) $\underline{\underline{m}}\left\langle^{*}\right\rangle, \underline{\underline{n}}\langle o j o\rangle, \underline{\mathrm{f}}\langle u j u\rangle$.

$\mathrm{G}(1)\langle\mathrm{a}\rangle$, (2) (3) $\langle\mathrm{y}\rangle,(4) \underline{\mathrm{m}} \underline{\mathrm{n}}\langle\mathrm{ovo}\rangle, \underline{\mathrm{f}}\langle\mathrm{oj}\rangle$.

$\mathrm{L}(1)(2)\langle e\rangle,(3)\langle y\rangle,(4) \mathrm{m} \underline{\underline{n}}\langle\mathrm{om}\rangle, \underline{\mathrm{f}}\langle\mathrm{oj}\rangle$.

$\mathrm{D}(1)\langle\mathrm{u}\rangle,(2)\langle e\rangle,(3)\langle y\rangle,(4) \underline{\mathrm{m}} \underline{\underline{u}}\langle\mathrm{omu}\rangle, \underline{\mathrm{f}}\langle\mathrm{oj}\rangle$.

I (1) $\langle o m\rangle,(2)\langle o j(u)\rangle$, (3) $\underline{m} \underline{n}\langle o m\rangle, \underline{f}\langle\varnothing j u\rangle$, (4) $\underline{m} \underline{n}\langle y m\rangle$, $\mathrm{f}\langle\operatorname{oj}(\mathrm{u})\rangle$.

Examples: заво́д, чу́вство, ка́рта, и́мя, ра́дость, портно́й, моро́женое, столо́вая.

1. $\mathrm{A}\langle *\rangle$ means $\mathrm{A}=\mathrm{G}$ for animate nouns and $\mathrm{A}=\mathrm{N}$ for inanimate nouns.

2. $N(4) \underline{m}\langle o j\rangle$ in stressed and $\langle y j\rangle$ in unstressed position.

3. $N\langle o\rangle$ in $m$ nouns ending in the suffixes $\langle$ išk $\rangle$, 〈išč $\rangle$, e.g., доми́шко, доми́ще, and in the nouns подмасте́рье, полуду́рье, мазло́, трепло́.

4. $\mathrm{N} \underline{\mathrm{f}}\langle\mathrm{a}\rangle, \mathrm{A} \underline{\mathrm{f}}\langle\mathrm{u}\rangle, \mathrm{I} \underline{\mathrm{m}}\langle\mathrm{ym}\rangle$ in proper names ending in the suffixes $\langle$ ov $\rangle,\langle$ in $\rangle$, е.g., Попо́в(a), Ники́тин(a).

5. NA $\langle\mathrm{e}\rangle, \mathrm{L}\langle\mathrm{y}\rangle, \mathrm{I}\langle\mathrm{em}\rangle$ in бытие́, житие́, питие́. ${ }^{9}$

6. $L D\langle y\rangle, I\langle e j(u)\rangle$ in лития́, паремия́, судия́.

7. LDI $\langle a\rangle$ in the numerals со́рок, девяно́сто, сто.

8. $I\langle o j\rangle$ in дитя́.

9. I 〈Øjú〉 in the numerals пять, шесть, семь, во́семь, де́вять, де́сять, два́дцать, три́дцать.

10. G2 (1) $\underline{\mathfrak{m}}\langle u\rangle$ in a large number of nouns, e.g., чай, конья́к, кероси́н, шум, наро́д. ${ }^{10}$

11. G3 〈á in ряд, след, час, шаг, шар, and G3 (4)= Gpl. There is a second variant $\mathrm{G} 3(4) \underline{\mathrm{f}}=\mathrm{Npl}$.

- Also in небытие́, инобытие́.

10 Cf. Gr 1970:378f.; Zaliznjak, 1967:282ff.; Stankiewicz, 1968:32ff. 
12. L2 (1) $\underline{\mathrm{m}}\langle\dot{u}\rangle, \underline{\mathrm{n}}\langle\dot{y}\rangle,(3) \underline{\mathrm{f}}\langle\dot{y}\rangle$ in a large number of nouns, e.g., нос, край, аэропо́рт, забытьё, кровь, тень. ${ }^{11}$

\subsection{Plural.}

$$
\begin{aligned}
& \mathrm{N}\langle y\rangle,\langle i\rangle,\langle a\rangle,(4)\langle y j y\rangle . \\
& A\left\langle^{*}\right\rangle . \\
& G\langle o f\rangle,\langle e j\rangle,\langle\emptyset\rangle,(4)\langle y x\rangle . \\
& L\langle a x\rangle,(4)\langle y x\rangle . \\
& D\langle a m\rangle,(4)\langle y m\rangle . \\
& I\langle a m i\rangle,(4)\langle y m i\rangle .
\end{aligned}
$$

1. $\mathrm{A}\left\langle^{*}\right\rangle$ means $\mathrm{A}=\mathrm{G}$ for animate nouns and $\mathrm{A}=\mathrm{N}$ for inanimate nouns.

2. $\mathrm{N}\langle\mathrm{y}\rangle$ in most $\underline{\mathrm{m}}$ and $\underline{\mathrm{f}}$ nouns, e.g., заво́д, жи́тель, музе́й, ка́рта, земля́, ра́дость, болга́рин, in n nouns with fixed stress ending in $\langle\mathrm{k}\rangle$ or $\langle\mathrm{x}\rangle$, e.g., я́блоко, брю́хо, and in the nouns коле́но, плечо́, у́хо, о́ко, дитя́.

3. $\mathrm{N}\langle\mathrm{i}\rangle$ in nouns ending in $\langle\mathrm{an}\rangle$ which drop the sg stem formative $\langle$ in $\rangle$ in the plural, e.g., крестья́нин, армяни́н, and in the nouns ба́рин, боя́рин, щыга́н.

4. $\mathbf{N}\langle a\rangle$ in most nn nouns, e.g., боло́то, по́ле, и́мя, in nouns which take the pl stem formative $\left\langle\varnothing_{\mathrm{j}}\right\rangle$, e.g., стул, друг, дя́дя, гроздь, in nouns which take the sg stem formative 〈onk > and the pl stem formative〈at〉, e.g., гусёнок, чертёнок, in the nouns господи́н, хозя́ин, in a large number of $m$ nouns with fixed sg stress on the stem and fixed pl stress on the desinence, e.g., дом, бе́рег, дире́ктор, коки́ль, and in a few $\underline{m}$ nouns with fixed stress on the desinence, e.g., рука́в. ${ }^{12}$

5. G〈of $\rangle$ in most $\underline{m}$ nouns ending in a hard non-palatal consonant or in $\langle j\rangle$, e.g., заво́д, музе́й, in most nouns which take the pl stem formative $\langle Ø \mathrm{j}\rangle$, е.g., дя́дя, гроздь, де́рево, in ñ nouns ending in $\langle\mathrm{k}\rangle$ with fixed $\mathrm{pl}$ stress on the desinence, e.g., озерко́, о́блако, in n nouns ending in the suffix 〈ik〉, e.g., ли́чико, in the nouns дре́вко, боло́тце, волоко́нце, кру́жевце, око́нце, верхо́вье, низо́вье, пла́тье, разво́дье, ýстье, остриё, and in the noun су́дно which drops the sg stem formative $\langle\mathrm{n}\rangle$ in the plural.

6. $G\langle e j\rangle$ in most $m$ nouns ending in a soft or palatal consonant except $\langle j\rangle$, е.g., жи́тель, ю́ноша, in most $\underline{f}$ nouns ending in a soft or palatal consonant except $\langle\mathrm{j}\rangle$ if the ending is stressed, e.g., до́ля, дежá,

11 Cf. Gr 1970:379ff.; Zaliznjak, 1967:285ff.; Stankiewicz, 1968:35ff.

12 Cf. Gr 1970:381f.; Zaliznjak, 1967:223f.; Stankiewicz, 1968:42ff. 
in $\underline{f}$ nouns ending in $\langle\mathrm{kl}, \mathrm{gl}, \mathrm{xl}\rangle$, e.g., са́кля, in $\underline{\mathrm{f}}$ (3) nouns, е.g., ра́дость, and in the nouns pácпря, сво́дня, тётя, о́бжа, мре́жа (archaic), ко́рча, ве́рша, семядо́ля, ма́рля, пу́тля, ходу́ля, кара́куля, ста́вня, схо́дня, пе́ня, плу́тня, чу́ня, при́горшня, по́ле, мо́ре, у́хо, о́ко, дитя́, коле́но, ве́че. ${ }^{13}$

7. $\mathrm{G}\langle\varnothing\rangle$ in most $\underline{f}$ and nouns, e.g., кápта, ли́ния, боло́то, и́мя, in nouns which take the sg stem formative 〈onk〉 and the pl stem formative 〈at〉, e.g., гусёнок, чертёнок, in nouns which take the sg stem formative $\langle$ in $\rangle$, e.g., крестья́нин, боя́рин, болга́рин, господи́н, хозя́ин, in $\mathbf{m}$ (2) nouns ending in a hard non-palatal consonant or in $\langle j\rangle$, e.g., слуга́, судья́, in the nouns де́верь, друг, князь, муж, сын, which take the pl stem formative $\langle\varnothing \mathrm{j}\rangle$, in the nouns во́лос, зубо́к, госпожа́, дере́вня, заря́, земля́, межа́, простыня́, шестерня́, and in a number of m nouns denoting members of nationalities or military units, paired objects, or units of measurement, e.g., грузи́н, румь́н, цыга́н, ту́рок, партиза́н, солда́т, каде́т, боти́нок, сапо́г, глаз, арши́н, ампе́р, грамм, раз, челове́к. ${ }^{14}$

8. I 〈mí 〉 in де́ти, лю́ди, and optionally in дочь, ло́шадь, дверь, зверь.

9. $N\langle y\rangle$ in proper names ending in the suffixes $\langle o v\rangle$, $\langle$ in $\rangle$, e.g., Попо́вы, Ники́тины.

10. $\mathrm{GL}\langle\mathrm{yx}\rangle, \mathrm{D}\langle\mathrm{ym}\rangle, \mathrm{I}\langle\mathrm{ymi}\rangle$ in ка́бельтов. ${ }^{15}$

\section{STEM FORMATIVES}

\subsection{SuffiXation.}

1. sg 〈in〉, e.g., крестья́нин, армяни́н, болга́рин, господи́н.

2. $s \mathrm{~g}\langle\mathrm{in}\rangle, \mathrm{pl}\left\langle\varnothing_{\mathrm{j}}\right\rangle$ in шýpuн.

3. $\mathrm{sg}\langle$ in $\rangle, \mathrm{pl}\langle\mathrm{ov}\rangle$ in хозя́ин.

4. sg 〈onk $\rangle, \mathrm{pl}\langle a t\rangle$, e.g., гусёнок, волчо́нок.

5. sg 〈onk $\rangle, \mathrm{pl}\langle$ onat〉 in бесёнок, чертёнок, щено́к.

6. $\mathrm{sg}\langle\mathrm{k}\rangle$ in цвето́к.

7. $\mathrm{sg}\langle\mathrm{ic}\rangle$ in ку́рица.

8. $\mathrm{sg}\langle\mathrm{n}\rangle$ in су́дно.

9. Nsg $\langle o s\rangle$ in Христо́c.

10. NAsg $\langle a\rangle$, GLDIsg $\langle a \mathfrak{a}\rangle$ in дитя́ $\langle$ detá- $\varnothing\rangle$.

13 Zaliznjak does not mention the word колено in this connection $(1967: 230)$.

14 Cf. Gr 1970:382; Zaliznjak, 1967:228; Stankiewicz, 1968:54f. None of these sources mentions the word земля in this connection.

15 Also in шввартóв according to Gr 1970:395. 
11. GLDIsg $\langle\dot{\mathrm{n}}\rangle, \mathrm{pl}\langle\mathrm{n}\rangle$ in бре́мя, вре́мя, ви́мя, зна́мя, и́мя, пла́мя, пле́мя, те́мя, which end in $\langle 0\rangle$, and in се́мя, стре́мя, which end in $\langle a\rangle$.

12. GLDIsg, $\mathrm{pl}\langle$ er $\rangle$ in дочь, мать.

13. $\mathrm{pl}\langle\emptyset \mathrm{j}\rangle$, е.g., брат, друг, ко́лос, де́рево, гроздь. ${ }^{16}$

14. $\mathrm{pl}\langle$ ovØj $\rangle$ in кум, сын.

15. $\mathrm{pl}\langle$ es〉 in дре́во (archaic), не́бо, чýдо.

\subsection{Palatalization.}

1. sg hard, pl soft in коле́но, сосе́д, чёрт.

2. Nsg soft, GDsg hard in госпо́дь.

3. Gpl hard in $f$ nouns ending in $\langle\dot{\mathrm{n}}\rangle$ preceded by a non-velar consonant if the ending is not stressed, e.g., пе́сня, and in the nouns са́жень, шестерня́. Exception: ба́рышня.

4. LDIpl hard in це́рковь.

\subsection{Alternation.}

1. $\mathrm{sg}\langle\mathrm{k}, \mathrm{g}, \mathrm{x}\rangle, \mathrm{pl}\langle\breve{\mathrm{c}}, \mathrm{z}, \breve{\mathrm{s}}\rangle$ in nouns which take the pl stem formative $\langle\varnothing \mathrm{j}\rangle$, е.g., клок, друг, and in the nouns óко, ýхо.

2. $\mathrm{sg}\langle\mathrm{o}\rangle, \mathrm{pl}\langle\mathrm{e}\rangle$ in чёрт.

3. Connective NAsg $\langle\dot{\varnothing}\rangle$, GLDIsg $\langle u ́\rangle$ (optional) in по́лдень, по́лночь.

\subsection{SUPPLETION.}

1. sg ребёнок, pl де́ти.

2. sg челове́к, $\mathrm{pl}$ лю́ци.

3. $\mathrm{Gpl}$ лет tо год.

\section{ACCENT CLASSES}

6.1. Class I. Fixed stress: approximately $98 \%$ of all substantives.

1. Fixed stress on the stem, е.g., тигр, заво́д, солда́т, гусёнок, чу́вство, ка́рта, ю́ноша, тетра́дь, столо́вая, шоссе́.

2. Fixed stress on the desinence, е.g., царь, стол, сапо́г, сон, словцо́, черта́, ступни́, любо́вь 〈lubł்-ø

6.2. Class II. Opposition between sg and pl stress: approximately 600 substantives.

16 Cf. Gr 1970:386f.; Zaliznjak, 1967:237; Stankiewicz, 1968:59f. 
1. sg stress on the stem, pl stress on the desinence, e.g., мácтер, сад, глаз, господи́н, ме́сто, мо́ре.

2. sg stress on the desinence, pl stress on the stem, e.g., вино́, перо́, дно, сук, кислота́, тягота́.

3. sg stress on the root, $\mathrm{pl}$ stress on the stem formative in дépeво, ка́мень, ко́лос, о́бод, по́вод, по́лоз, which take the pl stem formative $\left\langle\emptyset_{j}\right\rangle .^{17}$

4. sg stress on the stem formative, $\mathrm{pl}$ stress on the root in армяни́н, граждани́н, дворяни́н, мещани́н, селяни́н, славяни́н, христиани́н, чужани́н, which take the sg stem formative $\langle$ in $\rangle .^{18}$

5. Stress alternation in the root in зна́мя, óзеро.

6. Stress alternation in the stem formative in бесёнок, чертёнок.

6.3. Class Ia. Shift of stress in the plural: approximately 50 substantives.

1. Npl stress retracted, e.g., конь, гвоздь, крыльцо́, губа́, ноздря́.

2. NGpl stress retracted in де́ньги.

3. Gpl stress retracted in судия́.

6.4. Class IIa. Opposition between sg and pl stress and shift of stress in the plural: approximately 150 substantives.

1. Npl stress retracted, е.g., волк, во́лос, у́хо, дере́вня, ночь.

2. NGpl stress retracted in са́жень. ${ }^{19}$

3. Gpl stress retracted in кру́жево, ма́сло.

4. Gpl stress shifted to the desinence in овца́, свинья́, семья́, сестра́, судья́, гумно́, кольцо́, яйцо́, де́ти, лю́ди, хло́поты. ${ }^{20}$

6.5. Class Ib. Shift of stress in the singular (and in the plural).

1. Asg Npl stress retracted in ropá, доска́, крохá, ногá, порá, рекá, рука́, среда́, стена́, строка́, щека́, болона́, борода́, борона́, голова́, полоса́, середа́, сторона́. ${ }^{21}$

2. Nsg Npl stress retracted in у́голь (variant with mobile stress).

3. Nsg stress retracted in у́гол, у́горь, у́зел, and in the numerals во́семь, де́вять, де́сять, два́дцать, три́дцать, со́рок.

4. Nsg stress shifted to the desinence in заём, наём. ${ }^{22}$

17 The noun у́голь belongs to accent classes $I$ and Ib.

18 Also in coграждани́н. The noun семьяни́н belongs to accent class $\mathrm{I}$.

19 The variant caжéнь belongs to accent class $I$.

20 This rule is lacking in Gr 1970:441.

21 The nouns река, строка, полоса belong to accent classes Ia and Ib. The noun peka belongs to accent class II also.

22 Also in перенаём, поднаём. 
6.6. Class IIb. Opposition between sg and pl stress and shift of stress in the singular (and in the plural).

1. Asg stress retracted in верстá, водá, дрогá, душá, заря́, зимá, избá, косá, спина́, цена́. ${ }^{23}$

2. Asg stress retracted, Gpl stress shifted to the desinence in земля́.

3. Nsg stress shifted to the desinence in госпо́дь, перёд.

\section{THE FLEXION OF THE ADJECTIVE}

7.1. Categories.

7.1.1. Case: N, A, G, L, D, I.

7.1.2. Number: $\mathrm{sg}$, p1.

7.1.3. Gender: $\underline{\mathrm{m}}, \mathrm{f}, \underline{\mathrm{n}}$.

7.1.4. Attributiveness: LONG, SHORT.

7.1.5. Comparison: positive, comparative.

7.1.6. Flexion classes: (4), (5).

7.1.7. Accent classes: I, II, III, I/III, II/III, IIa, IIIa.

1. In the short form there is no case.

2. In the short comparative there is no gender and no number.

\subsection{FleXional SuFfixes.}

1. The regular LONG endings are given in section 4 above.

2. Nsg $\underline{m}\langle\varnothing\rangle, \underline{n}\langle 0\rangle, \underline{f}\langle a\rangle$, Asg $\underline{n}\langle 0\rangle, \underline{f}\langle u\rangle, N p l\langle y\rangle$ in adjectives ending in the stem formatives $\left\langle\emptyset_{\mathrm{j}}\right\rangle,\langle\mathrm{ov}\rangle$, $\langle$ in $\rangle$, e.g., во́лчий, чей, тре́тий, чёртов, дя́дин, and in мой, твой, свой, наш, ваш, госпо́день. The same sg endings in весь, одйн, тот, э́тот, and in сам, which has the variant Asg $\underline{\mathrm{f}}\langle$ 〈ojó $\rangle$. The same pl ending in двóe, тро́е, три, чети́pe.

3. Gsg $\underline{m} \underline{\underline{n}}\langle a\rangle$, Dsg $\underline{m} \underline{\underline{n}}\langle u\rangle$ in adjectives ending in the stem formatives $\langle o v\rangle,\langle$ in $\rangle$, е.g., мёртов. These endings are optional after the unstressed stem formative $\langle$ in $\rangle$, e.g., дя́дин.

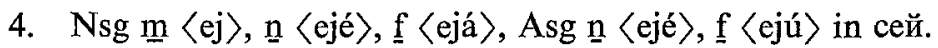

5. GLDsg $\mathrm{f}\langle e j\rangle$, Isg $\underline{\mathrm{f}}\langle\mathrm{ej}(u)\rangle$ in весь, сей, мой, твой, свой.

6. Isg $\underline{m} \underline{n}\langle\mathrm{em}\rangle, \mathrm{Npl}\langle\mathrm{e}\rangle, \mathrm{GLpl}\langle\mathrm{ex}\rangle, \mathrm{Dpl}\langle\mathrm{em}\rangle, \mathrm{Ipl}\langle\mathrm{emi}\rangle$ in весь, тот, э́тот.

7. Isg m- $\underline{m}\langle\mathrm{im}\rangle, \mathrm{Npl}\langle\mathrm{i}\rangle, \mathrm{GLpl}\langle\mathrm{ix}\rangle, \mathrm{Dpl}\langle\mathrm{im}\rangle, \mathrm{Ipl}\langle\mathrm{imi}\rangle$ in оди́н, cam.

8. $\mathrm{N} \underline{m} \underline{\underline{n}}\langle\mathrm{a}\rangle, \underline{\mathrm{f}}\langle\mathrm{y}\rangle, \mathrm{GLDI}\langle\mathrm{a}\rangle$ in полтора́.

9. $\mathrm{N} \underline{\mathrm{m}} \underline{\underline{n}}\langle\mathrm{a}\rangle, \underline{\mathrm{f}}\langle\mathrm{e}\rangle$ in два, óбa.

23 The nouns верста, заря, изба, коса belong to accent classes II and IIb. 
10. $\mathrm{GL}\langle\mathrm{x}\rangle, \mathrm{D}\langle\mathrm{m}\rangle, \mathrm{I}\langle\dot{m a ́}\rangle$ in два, три, четь́pe.

11. The SHORT positive endings are: $\mathrm{sg} \underline{\mathrm{m}}\langle\varnothing\rangle, \underline{\mathrm{n}}\langle\mathrm{o}\rangle, \underline{\mathrm{f}}\langle\mathrm{a}\rangle, \mathrm{pl}\langle\mathrm{y}\rangle$, e.g., нов, бога́т, учён.

12. The SHORT comparative ending is $\langle\mathrm{e}\rangle$, e.g., craбée $\langle$ slab-éj-e $\rangle$, моло́же 〈molož-Ǿ-e $\rangle$, crápwe $\langle$ star-Ø̆́̆-e $\rangle$. There is a second variant $\langle\varnothing\rangle$ after the comparative stem formative $\langle$ ej $\rangle$, е.g., слабе́й $\langle$ slab-éj- $\varnothing\rangle$.

7.3. FORMATIVE SUFFIXES.

1. Nsg $\underline{m}\langle$ ot $\rangle$ in тот, э́тот.

2. GLDI $\underline{m} \underline{n}\langle o j\rangle, \underline{f}\langle e j\rangle$ in óбa.

3. GLDI $\langle u\rangle$ in два.

4. GLDI $\langle 0\rangle$ in три, GLD $\langle 0\rangle$ in четь́ре.

5. comparative $\langle$ ej $\rangle$, е.g., слабе́e, беле́e.

6. comparative $\langle\varnothing\rangle$, е.g., ши́ре, моло́же, коро́че, ти́ше. ${ }^{24}$ There is a nonzero alternant in деше́вле.

7. comparative $\langle\varnothing \check{s}\rangle$ in бóльше, ме́ньше, лу́чше, ста́рше, да́льше, до́льше, ра́ньше, то́ньше, бо́льший, ме́ньший, лу́чший, ху́дший, вь́сший̆, ни́зший, ста́рший, мла́дший. There is a voiced alternant in глу́бже.

8. comparative $\langle$ ejø̆̌ $\rangle$, 〈ajØš $\rangle$, e.g., сильне́йший, велича́йший.

9. positive $\langle\mathrm{k}\rangle$ in бли́зкий, га́дкий, гла́дкий, жи́дкий, коро́ткий, ни́зкий, ре́дкий, сла́дкий, то́нкий, у́зкий.

10. positive 〈ok〉 in высо́кий, глубо́кий, далёкий, широ́кий.

\subsection{Alternation.}

1. SHORT $\mathrm{sg} \underline{\mathrm{m}}$ single $\langle\mathrm{n}\rangle$ in a number of adjectives ending in $\langle e n n\rangle$, e.g., блаже́нный. ${ }^{25}$

2. SHORT $\mathrm{sg} \mathbf{m}$ hard in adjectives ending in $\langle\dot{\mathrm{n}}\rangle$ preceded by a consonant, e.g., дре́вний, изли́шний.

3. SHORT sg $\underline{\mathrm{mf}}$ hard, $\mathrm{sg} \underline{\mathrm{n}}, \mathrm{pl}$ optionally hard in и́скренний.

4. SHORT hard, LONG soft in солёный (со́лон, солоне́e).

5. Connective NA $\langle\varnothing\rangle$, GLDI $\langle u\rangle$ in полтора́.

6. positive hard, comparative soft before the stem formative $\langle\varnothing \breve{s}\rangle$ in до́лгий, то́нкий.

7. positive $\langle k, t, g, d, z, x, s\rangle$, comparative $\langle\check{c}, \check{z}, \breve{s}\rangle$ before the stem formative $\langle\varnothing\rangle$, e.g., гро́мкий, коро́ткий, просто́й, дорого́й, молодо́й, нйзкий, ти́хий, высо́кий.

24 Cf. Gr 1970:402.

25 Cf. Zaliznjak, 1967:240, where the word э́кстренный should be added. 
8. positive $\langle o\rangle$, comparative $\langle e\rangle$ in лёгкий (ле́гче), дешёвый (деше́вле).

9. LONG comparative $\langle l a\rangle$ instead of $\langle$ olo $\rangle$ in молодо́й (мла́дший).

10. Suppletion in хоро́ший (лу́чше, лу́чшхй), плохо́й (ху́же, ху́дший).

\subsection{ACCENT.}

1. CLASS I: fixed stress in approximately $98 \%$ of all adjectives and 4000 participles, e.g., лука́вый, лука́в, лука́ва, лука́во, лука́вы, смешно́й, смешо́н 〈smešn-Ǿ〉, смешна́, смешно́, смешни́, сде́ланный 〈s-déla-n-yj〉, сде́лан, сде́лана, сде́лано, сде́ланы.

2. ClasS II: opposition between LONG and SHORT stress in approximately 40 adjectives and 1000 participles, e.g., горя́чий, горя́ч, горяча́, горячо́, горячи́, решённый, решён, решена́, решено́, решень́.

3. Class III: opposition between sg $\mathbf{f}$ and $\underline{n}$ stress in the SHORT form in approximately 230 adjectives and 45 participles, e.g., то́нкий, то́нок, тонка́, то́нко, то́нки, молодо́й, мо́лод, молода́, мо́лодо, мо́лоды, взя́тый, взят, взята́, взя́то, взя́ты.

4. CLASS I/III: two sg $\mathrm{f}$ stress variants in the SHORT form in вла́стный and in approximately 30 participles, e.g., пи́тый, пит, пи́та́, пи́то, пйты. 26

5. ClaSS II/III: two sg n stress variants in the SHORT form (and two pl stress variants as well) in бе́лый, высокий, глубокий, далёкий, дли́нный, жёлтый, коро́ткий, пёстрый, по́лный, ста́рый, тёмный, тёплый, у́мный, чёрный, широ́кий, е.g., по́лон, полна́, по́лно́, по́лнь́́. 27

6. Class IIa: opposition between LONG and sHORT stress and two pl stress variants in the SHORT form in лёгкий and све́жий, e.g., лёгок, легка́, легко́, лёгки́. ${ }^{28}$

7. Class IIIa: opposition between $\mathbf{s g} \underline{\underline{f}}$ and $\underline{n}$ stress and two $\mathrm{pl}$ stress variants in the SHORT form in approximately 40 adjectives, e.g., си́льный, си́лён, сильна́, си́льно, си́льны́, просто́й, прост, проста́, про́сто, про́сть́. ${ }^{29}$

26 In colloquial speech also in rне́вный, жесто́кжй, пла́внбй, скло́нный, схо́дный (all III).

27 In colloquial speech also in во́стрый, кра́сный, хи́трый, дрянно́й (all III).

28 In colloquial speech the adjectives rpémшы (IIIa), све́тльци (III), тёмный, тёплый, чёрный (all II/III) also belong to this accent class.

29 In colloquial speech in twice as many adjectives. According to Zaliznjak 1967:169 the word сильный belongs to accent class III, which is incorrect. 
8. The comparative stress is the same as the SHORT sg $\mathrm{f}$ stress, e.g., лука́вей(ший), смешне́й(ший), горяче́й, то́ньше 〈ton்-Ø̆ธ̌-e〉, тонча́йший, моло́же 〈molož-ǿ-e〉, мла́дший 〈mlad-Ø̆̌̆-yj〉, полне́й(ший), ле́гче 〈lexс̌-Ǿ-e〉, легча́йший, сильне́й(ший), про́ще 〈prosč-ǿ-e〉, просте́йший.

9. SHORT $\mathrm{sg} \underline{\mathrm{m}}$ stress on the stem in all mobile accent classes, e.g., горя́ч 〈garáćč- $\varnothing$, мо́лод, по́лон, лёгок.

10. SHORT sg $\underline{m}$ stress on the stem in больно́й, and also in до́лжен, which has no LONG form.

11. SHORT sg $\underline{m}$ stress on the ending in (в)о́стрый, у́мный, хи́трый, шу́стрый, and optionally in дурно́й, си́льный, сми́рный.

12. Stress alternation in the stem in счастли́вый (сча́стли́в).

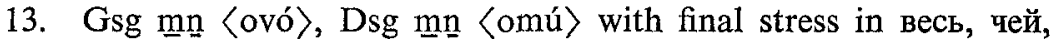
сей, оди́н, тот, сам, мой, твой, свой. ${ }^{30}$

14. Npl stress retracted in сам, о́ба, чет́́pe.

15. N stress shifted to the desinence in полтора́.

\section{THE PRONOUNS}

я $\langle\mathrm{m}\rangle$, ты $\langle\mathrm{t}\rangle$, мы $\langle\mathrm{n}\rangle$, вы $\langle\mathrm{v}\rangle$, он $\langle\mathrm{j}\rangle$, кто $\langle\mathrm{k}\rangle$, что $\langle\mathrm{c}\rangle$, себя $\langle\mathrm{s}\rangle$.

\subsection{Case Endings.}

1. $\mathrm{N}\langle\varnothing\rangle$ in $я$, ты, мы, вы, кто, что.

2. Nsg $\underline{\mathrm{m}}\langle\varnothing\rangle, \underline{\mathrm{n}}\langle\mathrm{o}\rangle, \underline{\mathrm{f}}\langle\mathrm{a}\rangle, \mathrm{Npl}\langle\mathrm{i}\rangle$ in он.

3. $\mathrm{A}=\mathrm{G}$ in я, ты, мы, вы, он, кто, себя, $\mathrm{A}=\mathrm{N}$ in что.

4. $\mathrm{G}\langle\mathrm{a}\rangle, \mathrm{LD}\langle\mathrm{e}\rangle, \mathrm{I}\langle\mathrm{oj}(\mathrm{u})\rangle$ in $я$, ты, себя.

5. GL $\langle a s\rangle, \mathrm{D}\langle\mathrm{am}\rangle, \mathrm{I}\langle\mathrm{ami}\rangle$ in $\mathrm{Mb}$, вы.

6. $\mathrm{G}\langle$ ovó $\rangle, \mathrm{L}\langle\mathrm{om}\rangle, \mathrm{D}\langle$ omú $\rangle, \mathrm{I}\langle\mathrm{em}\rangle$ in кто, что.

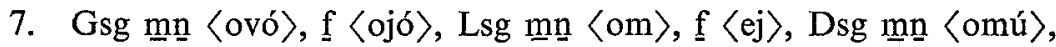
$\underline{\mathrm{f}}\langle\mathrm{ej}\rangle$, Isg $\underline{\mathrm{m}} \underline{\mathrm{n}}\langle\mathrm{im}\rangle, \underline{\mathrm{f}}\langle\mathrm{ej}(\mathrm{u})\rangle$, GLpl $\langle\mathrm{ix}\rangle, \mathrm{Dpl}\langle\mathrm{im}\rangle, \mathrm{Ipl}\langle\mathrm{imi}\rangle$ in oн.

\subsection{FoRMATIVE SUFFIXES.}

1. N $\langle y\rangle$ in ты, мы, вы.

2. $\mathrm{N}\langle$ to $\rangle$ in кто, что.

3. $\mathrm{G}\langle\varnothing\rangle$ in $\pi$.

4. GLDI $\langle\mathrm{ob}\rangle$ in ты, себя.

5. personal $\langle\mathrm{n}\rangle$, possessive $\langle\mathrm{oj}\rangle$ in $\pi /$ мой.

This rule is lacking in Zaliznjak 1967:168. 
6. possessive $\langle$ voj $\rangle$ in твой, свой.

7. possessive $\langle$ aš $\rangle$ in наш, ваш.

8. possessive $\langle\emptyset \mathrm{j}\rangle$ in чей.

8.3. Alternation.

1. NI hard, GLD soft in э, ты, себя.

2. N labial, GLDI dental in мы.

3. personal velar, possessive palatal in кто/чей.

4. $\mathrm{N}\langle$ on $\rangle$, GDI $\langle\mathrm{j}\rangle$, prepositional GLDI $\langle\dot{\mathrm{n}}\rangle$ in он.

5. $\mathrm{N}\langle\mathrm{ja}\rangle, \mathrm{GLDI}\langle\mathrm{mn}\rangle$ in $я$.

8.4. ACCENT. The stress is on the ending.

\section{A NOTE ON THE VERB}

9.1. CATEgories.

9.1.1. Person: $1,2,3$.

9.1.2. Number: $\mathrm{sg}$, pl.

9.1.3. Gender: $\underline{\mathrm{m}}, \underline{\mathrm{f}}, \underline{\mathrm{n}}$.

9.1.4. Tense: PRES, PAST.

9.1.5. Mood: IND, IMP, INF.

9.1.6. Aspect: IMPF, PERF.

9.1.7. Flexion classes: (1), (2).

9.1.8. Accent classes: I, II, III, Ia, IIa, IIIa.

1. There are six PREs forms: 1sg, pl, 2sg, pl, 3sg, pl.

2. There are four PAST forms: $\mathrm{sg} \underline{\mathrm{m}}, \underline{\mathrm{f}}, \underline{\mathrm{n}}, \mathrm{pl}$.

3. There are two IMP forms: sg, pl.

4. There is one INF form.

9.2. Flexional SUfFixes.

9.2.1. Person: PRES $1 \mathrm{sg}\langle\mathrm{u}\rangle, \mathrm{pl}\langle\mathrm{m}\rangle, 2 \mathrm{sg}\langle\breve{s}\rangle, \mathrm{pl}\langle\mathrm{t}\rangle, 3\langle\mathrm{t}\rangle$.

9.2.2. Number: IMP $\mathrm{pl}\langle\mathrm{ti}\rangle$.

9.2.3. Gender: PAST $\mathrm{sg} \underline{\mathrm{m}}\langle\emptyset\rangle$, $\underline{\mathrm{f}}\langle\mathrm{a}\rangle, \underline{\mathrm{n}}\langle\mathrm{o}\rangle, \mathrm{pl}\langle\mathrm{i}\rangle$.

9.2.4. Tense: PRES $(1)\langle 0\rangle,\langle u\rangle,\langle\varnothing\rangle,(2)\langle y\rangle,\langle a\rangle,\langle\varnothing\rangle$,

$$
\text { PAST }\langle 1\rangle,\langle\varnothing\rangle \text {. }
$$

9.2.5. Mood: $\operatorname{IMP}\langle\mathrm{i}\rangle,\langle\varnothing\rangle$,

$$
\text { INF }\langle\hat{t}\rangle,\langle\text { ty }\rangle,\langle\varnothing\rangle .
$$

1. The tense suffix precedes the person or gender suffix.

2. The mood suffix precedes the number suffix (if any). 
3. PRES $1 \mathrm{sg}\langle\emptyset\rangle, 3 \mathrm{pl}\langle\mathrm{u}\rangle,\langle\mathrm{a}\rangle$, other persons $\langle 0\rangle,\langle y\rangle$, e.g., учý, у́чат, у́чит.

4. PAST $\langle\varnothing\rangle$ after a consonant before $\langle\varnothing\rangle$ (except in шёл), elsewhere $\langle 1\rangle$, e.g., нёс, несла́. The PAST $\langle\varnothing\rangle$ is distinct from the sg $\underline{\mathrm{m}}\langle\varnothing\rangle$, cf.

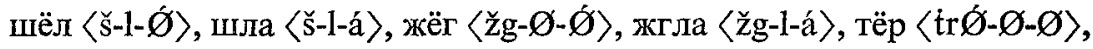
тёрла $\langle\operatorname{tr} \check{\varnothing}-1-a\rangle$.

5. IMP $\langle\varnothing\rangle$ after a single consonant if the suffix is not stressed, elsewhere $\langle i\rangle$, е.g., тронь, ляг, кради́, береги́.

6. INF $\langle\varnothing\rangle$ after a velar (which changes into a palatal), otherwise $\langle$ ty $\rangle$ if the suffix is stressed, $\langle\mathfrak{t}\rangle$ elsewhere, e.g., печь, нести́.

\subsection{Formative SUFFiXes (examples).}

1. PAST, INF $\langle a\rangle,\langle e\rangle$, 〈i $\rangle$, е.g., ждать, сиде́ть, говори́ть.

2. PRES, IMP $\langle\mathrm{j}\rangle,\langle\mathrm{v}\rangle$, е.g., де́лать, жить.

3. PAST, INF $\langle$ ova $\rangle$, PRES, IMP $\langle u j\rangle$, e.g., даровáTb.

4. PAST, INF $\langle a\rangle$, PRES, IMP $\langle\varnothing\rangle$, e.g., браTb.

5. INF $\langle\mathrm{nu}\rangle$, PRES, IMP $\langle\mathrm{n}\rangle$, PAST $\langle\varnothing\rangle$, e.g., га́снуть.

6. INF $\langle\varnothing \mathrm{e}\rangle$, PAST $\langle\varnothing\rangle$, e.g., тере́тb $\langle\operatorname{tr}-\varnothing e ́-t\rangle$.

\subsection{Alternation (examples).}

1. 1sg, 3pl hard, other persons soft, e.g., ждать.

2. $1 \mathrm{sg}, 3 \mathrm{pl}$ velar, other persons palatal, e.g., лгать.

3. 1sg palatal, other persons dental, e.g., сиде́ть.

4. PAST, INF velar, PRES, IMP palatal, e.g., пла́кать.

5. PAST, INF dental, PRES, IMP palatal, e.g., писа́ть.

6. INF fricative, other forms occlusive, e.g., вести́.

\subsection{ACCENT.}

1. ClASS I: fixed stress, e.g., печáтать, тре́бовать, владе́ть, чита́ть, дви́гать, бередйть, соса́ть, клева́ть, со́хнуть, лезть, блюсти́, воло́чь.

2. ClaSS II: opposition between PRES and PAST stress, e.g., балова́тb, колеба́ть, лечь, грызть, есть.

3. ClasS III: opposition between PRES and PAST stress and shift of stress in the PREs 1sg form, e.g., копи́ть, держа́ть, моло́ть, мочь.

4. Class Ia: shift of stress in the PAST sg f form in быть, вить, лить, пить.

5. Class IIa: opposition between PRES and PAST stress and shift of stress in the PAST sg form in гнить, жить, плыть, слыть, запере́ть, отпере́ть, умере́ть, взять, доня́ть, заня́ть, наня́ть, переня́ть, поня́ть, уня́ть, зача́ть, нача́ть, прясть, дать. 
6. Class IIIa: shift of stress in the PRES $1 \mathrm{sg}$ form and in the PAST sg $\mathrm{f}$ form in обня́ть, отня́ть, подня́ть, приня́ть, разня́ть, снять.

\section{TEXT}

The text transcribed below is the same as the one in Kortlandt 1973a: $08 \mathrm{ff}$, where the phonetic and phonemic transcriptions are given. The flexional suffixes are separated from the stem and the formatives by a hyphen.

\section{Morphonemic transcription}

<po pričín-am o katór-yx ne vrémo- $\varnothing$ tipér govori-t podróbn-o ja- $\varnothing$ đólžn- $\varnothing$ bý-1Ø postupí-t v lakéj-y k adn-omú pitirbúrgsk-omu činóvnik-u po famílij-e arlóv-u. bý-lo j-omú ókala tr̉ytcat-ý pat-ý let-ǿ y zvá-li j-ovó gijórgij-om yványč-om.

k ét-omu arlóv-u postupí-1Ø ja-Ǿ rádi j-ovó otc-á yzvésn-ovo gosudárstven-ovo čilavék-a katór-ovo ššitá-1Ø ja-Ǿ sirjózn-ym vrag-óm svoj-ovó dél-a. ja-Ǿ roššítyva-1Ø što žyvi-á u sýn-a po rozgovór-am katór-yjy uslýš- $\varnothing$ u y po bumág-am y zapísk-am kak-ýjy búd-Øu naxodí-t na stol-é ja- $\varnothing$ v podróbnosti-y yzuč- $\varnothing u ́$ plán-y y namérenij-a otc-á.

obyknovénn-o čas-óf $\mathrm{v}$ adínatcat- $\varnothing$ utr-á v moj-éj lakéjsk-oj tresčá-1 $\varnothing$

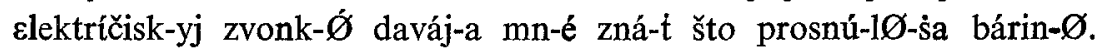
kagdá ja- $\varnothing$ s výčisčon-ym plátj-om y sapog-ámi prixodí-1 $\varnothing$ v spálìn-u gijórgij- $\varnothing$ yványč- $\varnothing$ sidé-1Ø nepodvížn-o v postél-y ne záspan-yj a skoréj-e utomlón-yj sn-óm y gladé-1Ø v adn-ú tóčk-u ne vykázyvaj-a po póvod-u svoj-ovó probuždénij-a nekak-óvo udovólstvij-a.ja-Ǿ pomogá-1Ø j-omú odevá-ṫ-sa a on- $\varnothing$ neoxótn-o podčiná-1Ø-s̉a mn-é mólč-a y ne zamečáj-a moj-ovó prisútstvij-a. potóm s mókr-oju ot umyvánj-a golov-ój y páxnušš-yj svéž-ymi dux-ámi on- $\varnothing$ š-1ǿ v stolóv-uju pí-t kófe- $\varnothing$. on- $\varnothing$ sidé-1Ø za stol-óm pí-1 $\varnothing$ kófe- $\varnothing$ y perelístyva-1 $\varnothing$ gazét-y a ja- $\varnothing$ y górnišn-aja pól-a počtítiln-o stojá-li u dvér-y y smotré-li na ñ-ovó. dv-á vzrósl-yx čilavék-a dolžn-ý bý-li s sám-ym sirjózn-ym vnemánij-om smotré-t kák trétj- $\varnothing$ pj-ót kófe- $\varnothing$ y gryż-ót suxárik-y. ét-o po vs̉-éj verajátnost-y smešn-ó y dík-o no ja-ǿ ne vídi-1Ø dla ṡob-á neč-ovó unizítiln-ovo v t-óm što prixodí-lo-s stojá-t ókala dvér-y xotá bý-1 $\varnothing$ tak-ým že dvớanín-om y obrazóvan-ym čilavék-om kák sam-ǿ arlóv-Ø.

u ṁn்-á tagdá načaná-la-š čaxótk-a a s ṅ-éju ješšó kóješto-Ø pažáluj považnéj-e čaxótk-y. ne znáj-Øu pod vlijánij-om li bolézñ-y yli načanáf̌̌- 
oj-ṡa peremén-y miravozzrénij-a katór-oj ja-Ǿ tagdá ne zamečá-1Ø mn-óju yzo dn்-á v dn்-Ø̊ ovladevá-la strásn-aja rozdražájušš-aja žážd-a obyknovénn-oj obyvátilsk-oj žýzñ-y. mn-é xoté-lo-ṡ dušévn-ovo pakój-a zdoróvj-a xaróš-ovo vózdux-a sýtosṫ-y. ja-Ǿ stanoví-1Ø-sa mičtátil-om y kák mičtátil-Ø ne zná-1Ø što-Ǿ sóbstven-o mn-é núžn-o.>

University of Leiden

\section{REFERENCES}

Durovič, L.

1964 Paradigmatika spisovnej ruštiny (Bratislava).

Gr 1970 Грамматика современного русского литературного языка (Москва).

Halle, M.

1959 The Sound Pattern of Russian (The Hague).

Isačenko, A. V.

1968 Die russische Sprache der Gegenwart I: Formenlehre (Halle, Saale).

Kiparsky, $\mathrm{V}$.

1962 Der Wortakzent der russischen Schriftsprache (Heidelberg).

Kortlandt, F. H. H.

1972a Modelling the Phoneme (The Hague).

1972b "Russian Conjugation", Tijdschrift voor Slavische taal- en letterkunde 1, 51-80.

1973a "Phonetics and Phonemics of Standard Russian", Tijdschrift voor Slavische taal- en letterkunde 2, 73-83.

1973b "Optional Features in Contemporary Russian", Dutch Contributions to the Seventh International Congress of Slavicists, 107-114.

Панов, М. В.

1963 “Об усовершенствовании русской орфографии”, Вопросы языкознания 2, 81-93.

1967 Русская фонетика (Москва).

Shapiro, M.

1969 Aspects of Russian Morphology (Cambridge, Mass.).

Stankiewicz, E.

1968 Declension and Gradation of Russian Substantives (The Hague).

Зализняк, А. A.

1963 "Ударение в современном русском склонении", Русский взык в национальной школе 2, 7-23.

1964 “Условное ударение' в русском словоизменении", Вопросы языкознания 1, 14-29.

1967 Русское именное словоизменение (Москва). 